X. C. ZHANG ${ }^{1}$, SH. Q. LIU' ${ }^{1}$, H. REN ${ }^{1}$, Y. I. ZENG ${ }^{2}$, and G. X. ZHAN ${ }^{1}$

\title{
ANALYSIS OF LONG-TERM DEPRESSION IN THE PURKINJE CELL CIRCUIT (A MODEL STUDY)
}

\author{
Received March 8, 2013
}

In the cerebellum, long-term depression (LTD) plays a key function in sculpting neuronal circuits to store information, since motor learning and memory are thought to be associated with such long-term changes in synaptic efficacy. To better understand the principles of transmission of information in the cerebellum, we, in our model, distinguished different types of neurons (type 1- and type 2-like) to examine the neuronal excitability and analyze the interspike interval (ISI) bifurcation phenomenon in these units, and then built a Purkinje cell circuit to study the impact of external stimulation on LTD in this circuit. According to the results of computational analysis, both climbing fiber-Purkinje cell and granule cell-Purkinje cell circuits were found to manifest LTD; the external stimuli would influence LTD by changing both depression time and depression intensity. All of the simulated results showed that LTD is a very significant factor in the Purkinje circuit networks. Finally, to deliver the learning regularities, we simulated spike timing-dependent plasticity (STDP) by increasing the $\mathrm{CaP}$ conductance.

Keywords: long-term depression (LTD), interspike interval (ISI), ion currents, depression time, depression intensity, spike timing-dependent plasticity (STDP).

\section{INTRODUCTION}

Long-term depression (LTD) is a well-known neurophysiological phenomenon; it is manifested as activity-dependent reduction in the efficacy of neuronal synapses developing after long patterned stimulations and lasting hours or longer. LTD is observed in many areas of the CNS; its mechanisms are dissimilar in different brain regions and depend upon the developmental stage [1]. In the cerebellum, LTD occurs in synapses on cerebellar Purkinje neurons; the latter receive two forms of excitatory inputs, one from a single climbing fiber and one from hundreds of parallel fibers [2].

Ito and colleagues were the first to documente LTD in the cerebellar cortex $[3,4]$. They observed that LTD results from coincident activation of parallel fiber and climbing fiber inputs onto Purkinje cells. Subsequent experiments were designed to test a hypothesis that LTD of excitatory synaptic transmission in the

\footnotetext{
1 Department of Mathematics, South China University of Technology, Guangzhou, China

${ }^{2}$ Biomedical Engineering Center, Beijing University of Technology, Beijing, China

Correspondence should be addressed to: X. C. Zhang

(e-mail: xuch0206@gmail.com).
}

cerebellar cortex is caused by a rise in the postsynaptic $\mathrm{Ca}^{2+}$ concentration [5]. Considering the importance of the cerebellum for motor learning, it has been widely proposed that LTD may serve as a cellular substrate of motor learning and memory in cerebellar cortical circuits $[4,6,7]$.

There are numerous studies on LTD induction in the climbing fiber-Purkinje cell and parallel fiber-Purkinje cell circuits. The LTD induced from climbing fibers was not associated with changes in the input or series resistance or with alterations in the strength of action of parallel fiber synapses [8]. Chen and Thompson applied a field potential recording technique from cerebellar slices to examine temporal conditions for the LTD development. The results suggested that these conditions for LTD induction demonstrate some similarity to those of associative learning for discrete motor responses [9]. Ekerot and Kano found that climbing fibers heterosynaptically depress parallel fiber-related responses in Purkinje cells [10].

According to the known pattern of the connecting system between different cells in the cerebellar cortex, we constructed a model of the Purkinje circuit network; this allowed us to separately study some dynamic properties of different types of cerebellar neuronal activity and LTD in the Purkinje circuit. 
Also, we analyzed some ion currents $\left(\mathrm{Ca}^{2+}, \mathrm{K}^{+}\right.$, and $\mathrm{Na}^{+}$) in these interconnected neurons. Finally, we simulated the spike timing-dependent plasticity (STDP) phenomenon and its relation to LTD in this model network.

\section{METHODS}

Based on the results of anatomy studies [11, 12] and data on the connection system between neurons [13], the following mode was accepted. The constructed Purkinje circuit network contains a Purkinje cell, a climbing fiber, granule cells, and Golgi cells. In order to effectively simplify the model, we used a certain proportion to reduce the complexity of the real Purkinje circuit system. One hundred seventy five parallel fibers from 175 granule cells are connected with 175 remote dendrites of the Purkinje cell; the axon of the climbing fiber intertwines with the main dendrite of the Purkinje cell and formes 13 synaptic connections [14]. Ten dendrites of the Golgi cells are connected with 10 parallel fibers, and 10 axons are connected with 10 dendrites of granule cells (Fig. 1). It should be noted that we used data related to climbing fibers of the rat considering that information on these fibers in mice could not be obtained.

According to the existing data, the hierarchy of the Purkinje circuit network is rather clear and easy to understand; some necessary physiological parameters in this model about all simulated neurons can be obtained from the respective papers [15-17]. Despite the introduced simplifications, the Purkinje circuit network constructed in our study is sufficiently similar to the real system.

According to the data of theoretical analysis, single neurons in our model are described as being based on the conduction model, and the morphology of each neuron is characterized by a compartmental model. Considering the morphological characteristics, different parts of the neurons can be depicted by various compartment numbers. The basic theory of electrical signal transmission is described by the Rall's cable model, and its discrete format is a neuronal compartment model [15-18]. Naturally, different compartments of the cells possess different compositions of ion channels and some specific initial ion variables. Some necessary parameters and neuronal equations employed in our network can be acquired in the paper by Eccles et al. [19].

The Purkinje circuit network in our study was modeled using NEURON software, and we used MATLAB software to process the data; the simulation results have been repeatedly proved.

\section{RESULTS}

As was described in former publications [20, 21], the Purkinje cell receives two significantly differing afferent excitatory fiber inputs. Parallel fibers establish synaptic contacts with cortical granule cells, while climbing fibers form synapses on the dendrites of the Purkinje cells. Before we further analyzed LTD in the Purkinje circuit, we dynamically analyzed the processes in the above-mentioned three kinds of

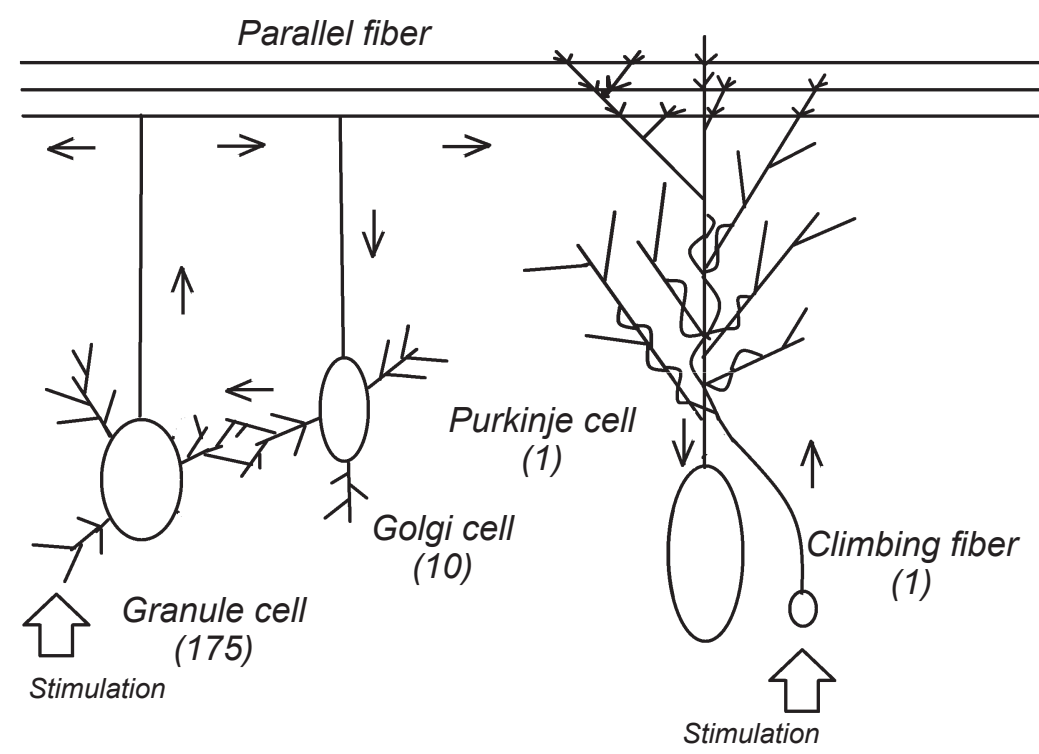

Fig. 1. Scheme of the modeled cerebellar cortex circuit. One Purkinje cell, 175 granule cells, one climbing fiber, 10 Golgi cells, and 175 parallel fibers are included. Only Golgi cells exert inhibitory influences on granule cells; other neuronal types produce excitatory effects.

Р и с. 1. Схема модельованої мережі мозочкової кори. 


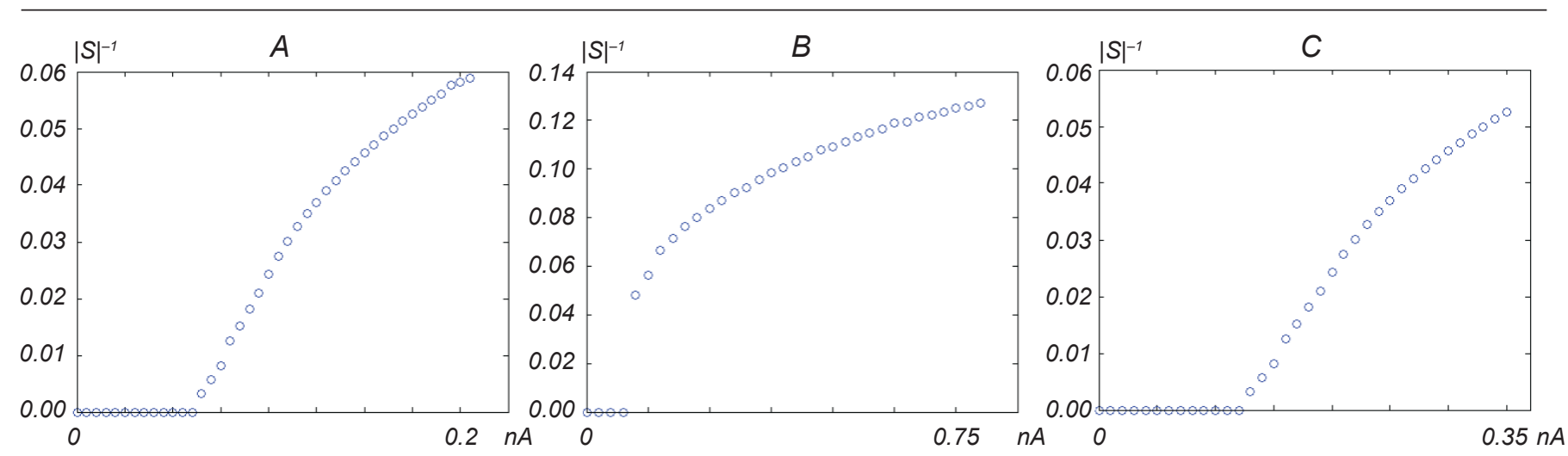

F i g. 2. Frequency vs. current $(f-I)$ curves (A-C) for three different neurons included in the model. A) Granule cell, B) climbing fiber, C) Purkinje cell. Abscissa) Intensity of direct-current stimulation, nA; ordinate) discharge frequency, $\mathrm{mean} \mathrm{ISI}^{-1}, \mathrm{msec}^{-1}$.

Р и с. 2. Графіки залежності частоти розряду від струму $(f-I)$ для трьох видів різних нейронів $(A-C)$, включених у модель.
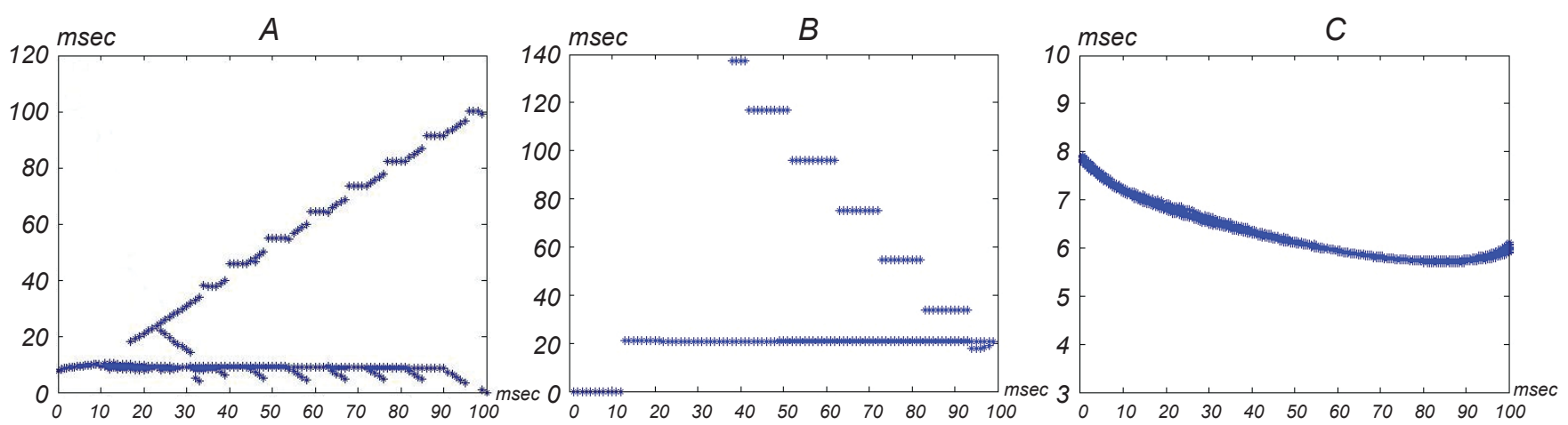

F i g. 3. ISI bifurcation diagrams (A-C) for three different neuronal types. A) Granule cell; B) climbing fiber; C) Purkinje cell. The stimulus intensities were $0.9,0.05$, and $0.29(t / 100<m)$, where $t$ is the threshold, and $m$ changes from 1 to 100 .

Р и с. 3. Діаграми біфуркацій міжімпульсних інтервалів для трьох видів нейронів $(A-C)$.

neurons separately.

Dynamic analysis to the Purkinje circuit network. The respective neurons and dynamical models of spike generation displayed two different types of threshold behavior under conditions of steady-current stimulation. Type 1-like neurons demonstrated firing frequency vs. current $(f-I)$ curves with continuous transition from a zero frequency to arbitrarily low frequencies of firing. Type 2-like neurons were characterized by $f-I$ curves showing an abrupt onset of repetitive firing at a nonzero firing frequency [22]. Since different types of neurons determine various dynamic properties, we classified different neurons in this circuit firstly to compare the neuronal excitability.

In Fig. 2, it is easy to distinguish three different types of neurons. With increase in the strength of external stimuli (direct current), the spiking frequency of granule cells and Purkinje cell both increased continuously; thus, they belong to type 1-like neurons.
In contrast, the frequency of climbing fiber spiking suddenly jumped from 0 to 0.042 ; thus this unit belongs to type 2-like neurons. It seems that the climbing fiber is relatively insensitive to the stimulus intensity. We can gain an insight into the ample dynamic properties between the two above types. This includes phaseresponse curves, synchrony, and adaptation. Then, we primarily studied the ISI bifurcation among the above three different neuronal types.

In Fig. 3, we can see that when we stimulate three different neurons with rectangular current pulses and change the parameters of the latter, the respective ISI bifurcation diagrams demonstrate significant specificities. The ISI diagram of the granule cell shows distinct period-adding bifurcation and period-doubling bifurcation phenomena. The climbing fiber exhibits an inverse period-adding bifurcation phenomenon. However, the respective changes in the Purkinje cell are relatively mild. The diversiform dynamic 

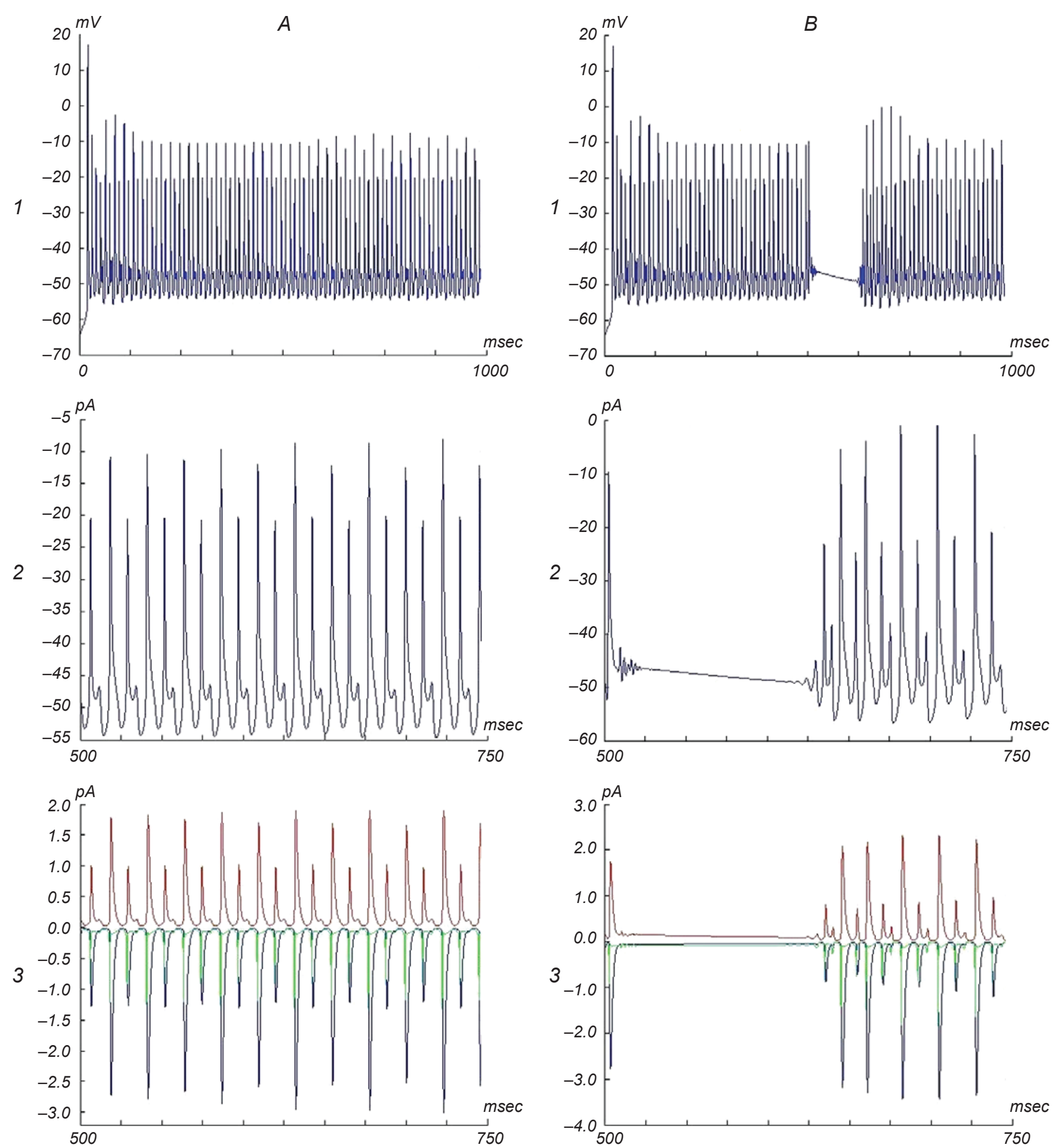

F i g. 4. Firing patterns of the Purkinje cell and $\mathrm{Ca}, \mathrm{K}$, and $\mathrm{Na}$ currents in the absence of stimulation of the granule cell (A1-3, respectively) and the corresponding records at a $0.9 \mathrm{nA}$ stimulation of the granule cell (B1-3).

Р и с. 4. Патерни розряду клітини Пуркін'є та кальцієвих, калієвих та натрієвих струмів за відсутності стимуляції гранулярної клітини (A1-3 відповідно) та аналогічні записи при стимуляції гранулярної клітини струмом 0.9 нА (B1-3). 

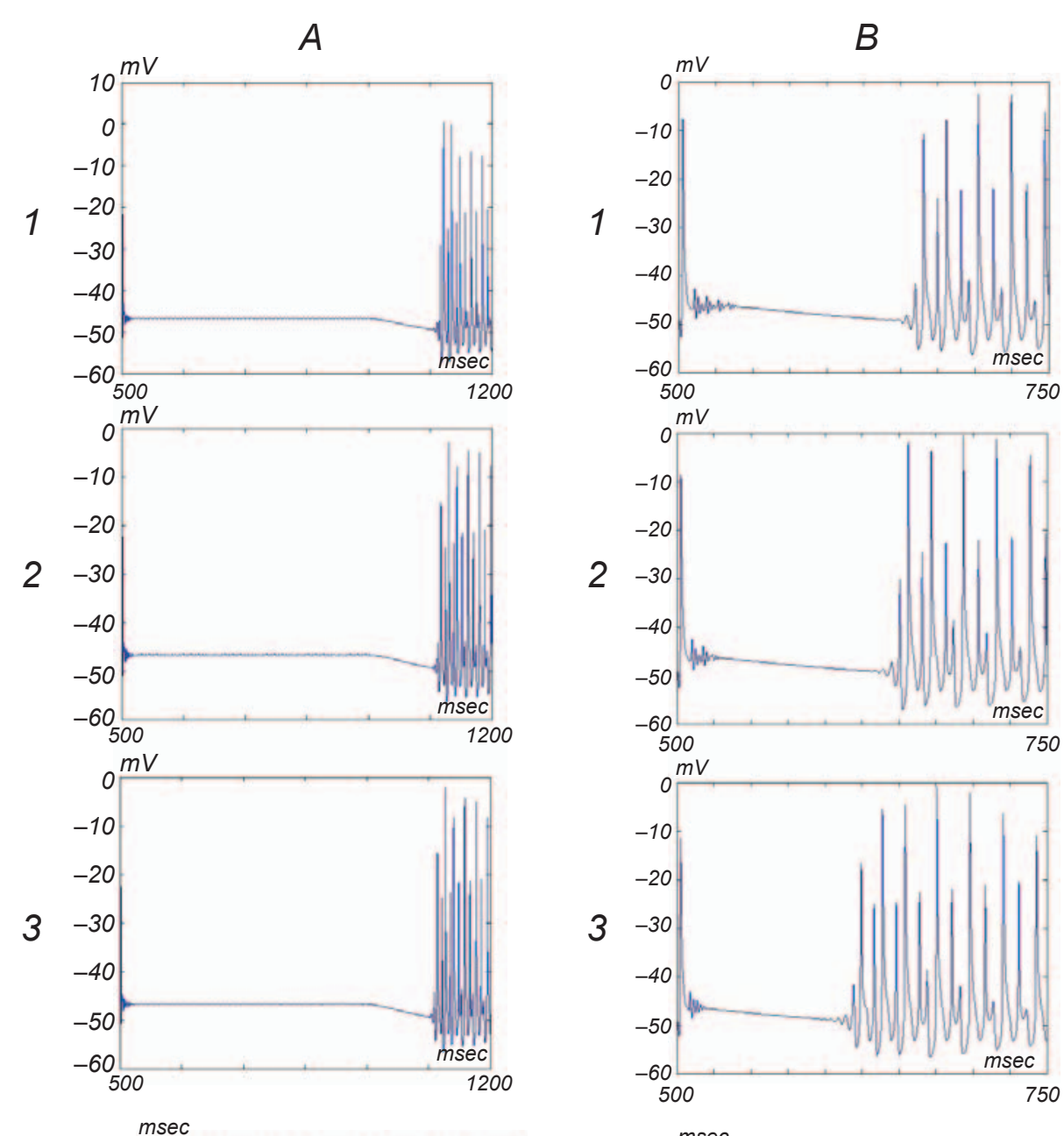

F i g. 5. Characteristics of spiking and LTD in the modeled circuits. A) Climbing fiber-Purkinje cell circuit. A1-3) Firing of the Purkinje cell at stimulus intensity applied to the climbing fiber of $0.7,0.9$, and $1.1 \mathrm{nA}$, respectively. A4 and A5) Depression time and depression intensity in the climbing fiber, respectively. B1-5) Analogous illustrations for the granule cell-Purkinje cell circuit.

Р и с. 5. Характеристики імпульсації та довготривалої депресії в модельованих мережах.
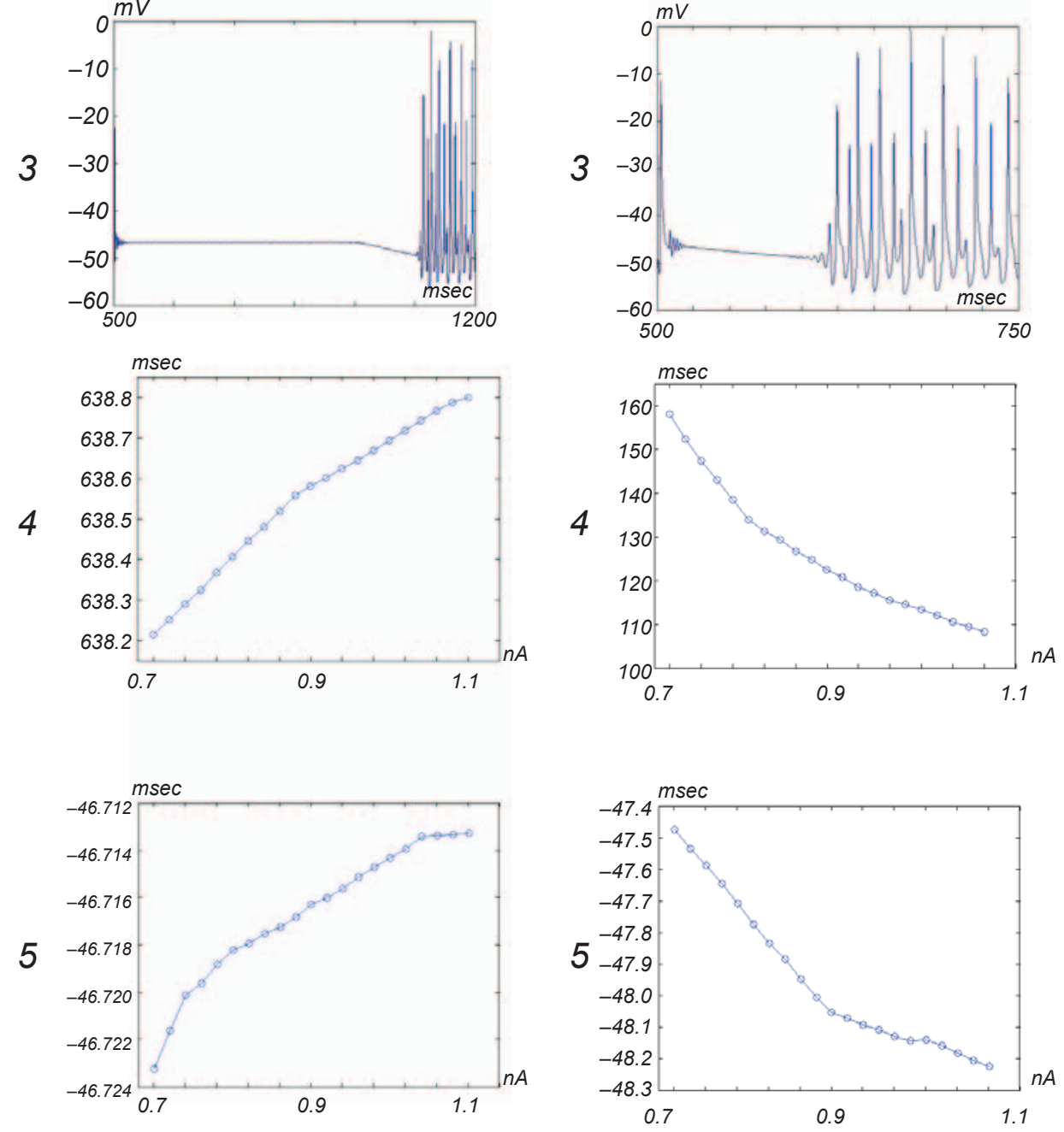

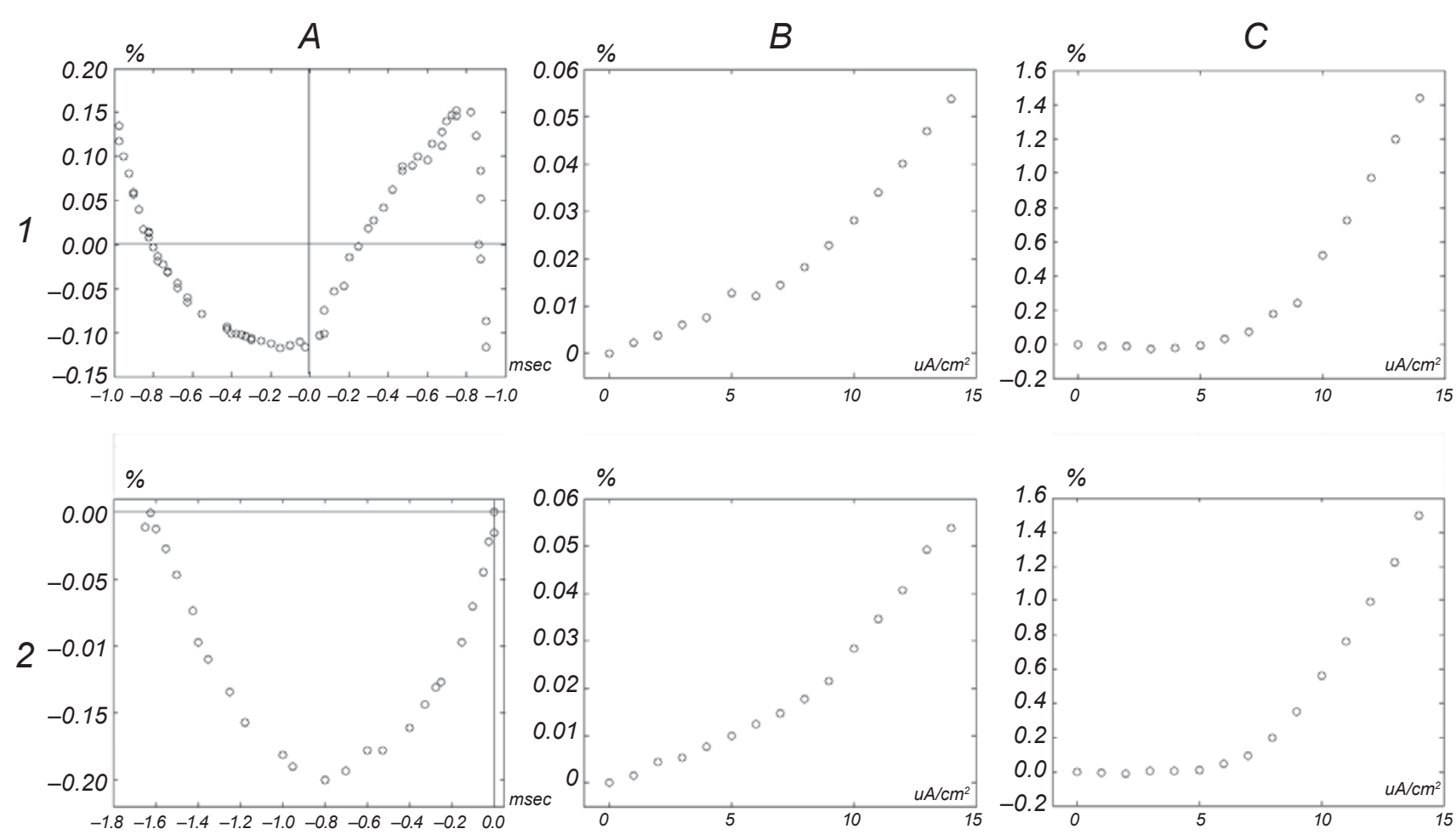

F i g. 6. Normalized changes in the EPSP potential with change in the spike time (A), those in the mean ISI with change in the CaP conductance (B), and change in the mean potential with change in the CaP conductance (C) in the granule cell-Purkinje cell circuit (1) and climbing fiber-Purkinje cell circuit (2).

P и с. 6. Нормовані зміни величини ЗПСП при варіюванні тривалості імпульсу $(A)$, середнього міжімпульсного інтервалу при варіюванні СаР-провідності $(B)$ та середнього значення потенціалу при варіюванні цієї провідності $(C)$ у мережах гранулярний нейрон - клітина Пуркін'є (1) та ліаноподібне волокно - клітина Пуркін'є (2).

properties motivated us to roundly analyze the LTD development in the above neurons.

Synaptic depression in the stimulated Purkinje circuit network. The elementary concept of the Marr-Albus theory is that the climbing fiber serves as a source of the "teaching signal," which induces long-lasting changes in the strength of synchronous activation of the parallel fiber inputs. Observations of LTD in the latter inputs have provided some support for theories of this type, but their validity remains controversial. So, we assay the LTD phenomenon in the granule cell-Purkinje cell circuit principally, since LTD can transfer information necessary for memory and motor learning processes [23-25]. In order to better research LTD in the Purkinje cell, we first examined the depression function in the respective synapses.

We stimulated the granule cell within a 500 to $501 \mathrm{msec}$ window whith 1-msec-long stimuli. Figure 4 illustrates the detailed firing pattern of the Purkinje cell and different ion currents in this cell without any stimulation applied to the granule cells (A1-3) and the respective records in the case of stimulation whith a $0.9 \mathrm{nA}$ intensity applied to the parallel fiber (B1-3). It is easy to observe a clear depression after $500 \mathrm{msec}$ and the patterns of $\mathrm{I}_{\mathrm{Ca}}, \mathrm{I}_{\mathrm{K}}$, and $\mathrm{I}_{\mathrm{Na}}$ related to every spike generated by the Purkinje cell. The depression period in the Purkinje cell and those of $\mathrm{I}_{\mathrm{Ca}}, \mathrm{I}_{\mathrm{K}}$, and $\mathrm{I}_{\mathrm{Na}}$ are synchronous. The analogous results could be observed upon climbing fiber-Purkinje cell stimulation.

To make the aforementioned analyses more conclusive, we changed the intensity of external stimuli to study the impact of this parameter on depression. In Fig. 5, it can be seen that during climbing fiberPurkinje cell stimulation, the depression duration and depression intensity changed to a limited extent when the stimulus intensity increased, although the A4 and A5 panels both show a slow upward trend. However, the depression time changes were clear during granule cell-Purkinje cell circuit stimulation. The depression time shortened with increases in the stimulus intensity (B4). In addition, the depression strength decreased in 
a parallel manner (B5). Thus, the simulation results demonstrate that the characteristics of external stimuli have a strong influence on the depression parameters.

Spike timing-dependent synaptic plasticity (STDP) in the Purkinje circuit network. Synaptic plasticity is the ability of a synaptic connection between two neurons to change the strength of its action in response to either use or disuse of transmission over this synaptic pathway [26]. According to the Hebbian theory, synaptic plasticity is one of the most important neurophysiological/ neurochemical mechanisms responsible for learning and memory processes in the CNS. In hippocampal neurons, Bi and Poo [27] have already simulated some critical windows for the induction of synaptic potentiation and depression. Based on the results of their research, we mainly analyzed synaptic depression or potentiation in the cerebellum.

As was mentioned above in the Introduction, $\mathrm{Ca}^{2+}$ plays a crucially significant role in the induction of LTD and LTP (long-term potentiation), especially in the cerebellum. As can be seen in Fig. $6 \mathrm{~A} 1$, when we gradually increased the $\mathrm{CaP}$ conductance, the simulated critical window for the induction of synaptic depression or potentiation in the granule cell - Purkinje cell cirquit looks like a recumbent "S." This is rather similar to the assumed rule of synaptic modification, and the graph from Bi and Poo [27] looks like a part of A1, where the spike time is the difference between the postsynaptic spike time and presynaptic spike time. Meanwhile, the mean ISI and potential both increase with increase in the $\mathrm{CaP}$ conductance (B1, C1). From A2, it is obvious that the normalized change in the EPSP potential in the climbing fiber - Purkinje cell decreases first and then increases gradually, and both changes in the mean ISI and potential increase with increase in the CaP conductance (B2, C2).

In previous experiments, only LTD appeared in the Purkinje cell. The opposite phenomena, i.e., LTP could not be produced. However, the simulation results described above showed that both LTD and LTP may be observed in the granule cell-Purkinje cell circuit. This finding may help us to more deeply understand regularities of the learning process in the Purkinje circuit.

\section{DISCUSSION}

Considering the results of previous studies, the constructed model Purkinje network is rather similar to the real system. In this paper, we mainly analyzed some dynamic properties of spiking, ion currents, LTD, and STDP in the Purkinje circuit. There are some aspects of the respective findings, which should be discussed.

(i) The examined three different neuronal types possess abundant dynamic properties. According to the classification of the types of neuronal excitability, granule cells and Purkinje cells belong to type 1-like neurons, while climbing fibers belong to type 2-like neurons that are not dramatically sensitive to stimulus intensity. The ISI bifurcation diagrams plotted for different neuronal types display abundant periodadding bifurcation and period-doubling bifurcation phenomena.

(ii) Long-term depression appears in both the granule cell-Purkinje cell circuit and the climbing fiber-Purkinje cell circuit. In the former cell circuit, external stimuli can influence firing of the Purkinje cell, intensely affecting the depression time and depression intensity. During the depression period, all examined ion currents (including $\mathrm{Ca}^{2+}, \mathrm{K}^{+}$, and $\mathrm{Na}^{+}$currents) are synchronized in the Purkinje cell. Comparable results were obtained for the climbing fiber-Purkinje cell circuit.

(iii) The results of simulation related to spike timing-dependent synaptic plasticity (STDP) are more convincing. In the granule cell-Purkinje cell circuit, we found that both LTD and LTP develop when the $\mathrm{CaP}$ conductance increases. Furthermore, changes in the mean ISI and potential increase gradually. However, only LTD is produced in the climbing fiberPurkinje cell circuit. The mean ISI and potential also increase here with increase in the $\mathrm{CaP}$ conductance.

Based on the findings in the previous analyses, the constructed Purkinje circuit has a clear network configuration and encompasses many functions. Thus, this type of circuit modeling should attract considerable attention. In this paper, we analyzed, as was mentioned above, some dynamic properties of three different neuronal types, LTD in the Purkinje network, and STDP, i.e., the phenomenon influencing learning regularities. This prepares us to thoroughly understand the mechanisms of motor learning and memory; these mecanisms will be our goal in future research. In fact, some results described in this paper are surprisingly similar to results of neurophysiological experiments in vivo. We believe that certain basic properties related to motor learning in the cerebellum may be further clarified using our simulations of the cerebellar Purkinje circuit network. 
The authors, X. C. Zhang, Sh. Q. Liu, H. Ren, Y. I. Zeng, and G. X. Zhan, confirm that they have no conflict of interest.

The authors would like to acknowledge the generous support by the National Undergraduates Innovating Experimentation Project of China, No. 111056144.

Appendix. Supporting information. Supplementary data associated with this article can be found in the online version at http://neuromorpho.org/

Кс. Ц. Жанг

\section{АНАЛІЗ ДОВГОТРИВАЛОЇ ДЕПРЕСІЇ В НЕЙРОННІЙ МЕРЕЖІ КЛІТИНИ ПУРКІН'Є (МОДЕЛЬНЕ ДОСЛІДЖЕННЯ)}

${ }^{1}$ Відділ математики, Південно-Китайський університет технології, Гуанчжоу (Китай)

${ }^{2}$ Центр біомедицинських технологій Пекинського університету технології (Китай)

$\mathrm{P}$ е 3 ю м е

У мозочку довготривала депресія (ДД) відіграє ключову роль у пристосуванні нейронних мереж до накопичення інформації, оскільки моторне навчання та пам'ять, як вважають, асоційовані з подібними тривалими змінами синаптичної ефективності. Намагаючись краще зрозуміти принципи передачі інформації в мозочку, в перебігу дослідження збудливості нервових клітин та аналізу феномена біфуркації міжімпульсних інтервалів у цих нейронах ми диференціювали в нашій моделі різні види нейронів (першого і другого типів). Потім була сформована модель нервової мережі клітини Пуркін'є для дослідження впливів зовнішньої стимуляції на ДД у такій мережі. Відповідно до результатів комп'ютерного аналізу, ДД проявляється і в мережі «ліаноподібне волокно-клітина Пуркін'є», і в мережі «гранулярна клітина-клітина Пуркін'є». Зовнішня стимуляція може впливати на ДД, змінюючи як час, так і інтенсивність депресії. Згідно з результатами моделювання, ДД $€$ дуже істотним фактором при функціонуванні мереж, котрі містять у собі клітини Пуркін'є. Нарешті, ми, щоб виявити закономірності процесу навчання, за допомогою збільшення СаР-провідності моделювали пластичність, залежну від часу генерації піка (STDP).

\section{REFERENCES}

1. P. V. Massey and Z. I. Bashir, "Long-term depression: multiple forms and implications for brain function," Trends Neurosci., 30, No. 4, 176-84 (2007).

2. D. Purves, G. J. Augustine, D. Fitzpatrick, et al., Neuroscience (4th edition), Sinauer Associates, Sunderland (MA) (2008).

3. M. Ito and M. Kano, "Long-lasting depression of parallel fiber-
Purkinje cell transmission induced by conjunctive stimulation of parallel fibers and climbing fibers in the cerebellar cortex," Neurosci. Lett., 33, 253-2589 (1982).

4. M. Ito, M. Sakurai, and P. Tongroach, "Climbing fiber induced depression of both mossy fiber responsiveness and glutamate sensitivity of cerebellar Purkinje cells," J. Physiol., 324,113134 (1982).

5. A. Konnerth, J. Dreessen, and G. J. Augustine, "Brief dendritic calcium signals initiate long-lasting synaptic depression in cerebellar Purkinje cells," Neurobiology, 89, No. 15, 70517055 (1992).

6. A. Aiba, M. Kano, C. Chen, et al., "Deficient cerebellar longterm depression and impaired motor learning in mGluR 1 mutant mice," Cell, 79, 377-388 (1994).

7. D. J. Krupa, J. K. Thompson, and R. F. Thompson. "Localization of a memory trace in the mammalian brain," Science, 260, 989-991 (1993).

8. C. Hansel and D. J. Linden, "Long-term depression of the cerebellar climbing fiber-Purkinje neuron synapse," Neuron, 26, 473-482 (2000).

9. C. Chen and R. F. Thompson. "Temporal specificity of longterm depression in parallel fiber-Purkinje synapses in rat cerebellar slices," Learning Memory, 2, 185-198 (1995).

10. M. F. Bear, B. W. Connors, and M. A. Paradios, Neuroscience: Exploring the Brain, Lippincott Williams \& Wilkins, Maryland (2001).

11. A. Longstaff, Instant Notes in Neuroscience, Springer-Verlag, New York (2000).

12. F. Fabbro, "Introduction to language and cerebellum," J. Neurolinguistics, 13, 83-94 (2000).

13. J. T. Davie, B. A. Clark, and M. Häusser, "The origin of the complex spike in cerebellar Purkinje cells," J. Neurosci., 28, No. 30, 7599-7609 (2003).

14. S. Solinas, L. Forti, E. Cesana, et al., "Fast-reset of pacemaking and theta-frequency resonance patterns in cerebellar Golgi cells: Simulations of their impact in vivo," Front. Cell Neurosci., 1, No. 4, 1-9 (2007).

15. W. M. Yamada, C. Koch, and P. R. Adams, Methods in Neuronal Modeling, MIT Press, Cambridge (Massachusetts) (1987).

16. M. Migliore and G. M. Shepherd, "Dendritic action potentials connect distributed dendrodendritic microcircuits," J. Comput. Neurosci., 24, 207-221 (2008).

17. W. Akemann and T. Knopfel, "Interaction of Kv3 potassium channels and resurgent sodium current influences the rate of spontaneous firing of Purkinje neurons," J. Neurosci., 26, No. 17, 4602-4612 (2006).

18. L. Wang and S. Q. Liu, "Neural circuit and its functional roles in cerebellar cortex," Neurosci. Bull., 27, No. 3, 173-184 (2011).

19. J. C. Eccles, R. Llinis, and K. Sasaki, "The excitatory synaptic action of climbing fibers on the Purkinje cells of the cerebellum," J. Physiol., 182, 268-296 (1966).

20. S. L. Palay and V. Chan-Palay, Cerebellar Cortex: Cytology and Organization, Springer-Verlag, Berlin, Heidelberg, New York (1974).

21. N. Kashiwabuchi, K. Ikeda, K. Araki, et al., "Impairment of Motor Coordination, Purkinje Cell Synapse Formation, and Cerebellar Long-Term Depression in GluR \&2 Mutant Mice," Cell, 81, 245-252 (1995).

22. T. Tateno, A. Harsch, and H. Robinson, "Threshold firing frequency-current relationships of neurons in rat 
somatosensory cortex: type 1 and type 2 dynamics," J. Neurophysiol., 92, 2283-2294 (2004).

23. A. M. Swensen and B. P. Bean, "Ionic mechanisms of burst firing in dissociated Purkinje neurons," J. Neurosci., 23, No. 29, 9650-9663 (2003).

24. J. C. Eccles, M. Ito, and J. Szentagothal, The Cerebellum as a Neuronal Machine, Springer-Verlag, Berlin, Heidelberg \& New York (1967).

25. J. R. Hughes, "Post-tetanic potentiation," Physiol. Rev., 38,
No. 4, 91-113 (1958).

26. D. L. Cook, P. C. Schwindt, L. A. Grande, and W. J. Spain, "Synaptic depression in the localization of sound," Nature, 421, 66-70 (2003).

27. G. Q. Bi and M. M. Poo, "Synaptic modifications in cultured hippocampal neurons: dependence on spike timing, synaptic strength, and postsynaptic cell type," J. Neurosci., 18, 10464 10472 (1998). 